\title{
A STUDY ON STARTUPS OF AGRICULTURE
}

\author{
${ }^{1}$ Shivaprasad BS, ${ }^{2}$ N. Raghavendra \\ ${ }^{1,2}$ Assistant Professor, Jain Institute of Business Management, Kanakapura, India. \\ 1'shivaajibsp@gmail.com, ${ }^{2}$ raghu0565@gmail.com
}

\begin{abstract}
Agriculture in India is composed of many crops, mainly with the food staples being rice and wheat. It also includes pulses, tuber crops, sugarcane, oilseeds, and such non-food items. India is holding many ranks in production of crops, aquaculture, horticulture, fruits \&vegetables and animal husbandry. The percentage of agriworkers in India is decreasing year by year. Approximately 29 farmers killing themselves per day in India. The paper is about to discuss the problems behind the suicides and the startups which can overcome those problems.
\end{abstract}

\section{Keywords: Agri Startups, Agri technology, Farmer Suicides, Production}

\section{INTRODUCTION}

Agriculture in India is composed of many crops, mainly with the food staples being rice and wheat. It also includes pulses, tuber crops, sugarcane, oilseeds, and such non-food items as cotton, tea, coffee, rubber, and jute (a glossy fiber used to make burlap and twine). India is a fisheries giant as well.

\section{Rankings:}

- India ranks second worldwide in farm outputs. As per 2018, agriculture employed $50 \%$ of the Indian work force and contributed 17-18\% to country's GDP.

- In 2016, agriculture and allied sectors like animal husbandry, forestry and fisheries accounted for $15.4 \%$ of the GDP (gross domestic product).

- India ranks first in the world with highest net cropped area followed by US and China.

- As per the 2014 FAO world agriculture statistics India is the world's largest producer of many fresh fruits like banana, mango, guava, papaya, lemon and vegetables like chickpea, okra and milk, major spices like chili pepper, ginger, fibrous crops such as jute, staples such as millets and castor oil seed.

- India is the second largest producer of wheat and rice, the world's major food staples. ${ }^{[10]}$

- India is currently the world's second largest producer of several dry fruits, agriculture-based textile raw materials, roots and tuber crops, pulses.

- India is ranked under the world's five largest producers of over $80 \%$ of agricultural produce items, including many cash crops such as coffee and cotton, in 2010. India is one of the world's five largest producers of livestock and poultry meat, with one of the fastest growth rates, as of 2011.

- Aquaculture and catch fishery is amongst the fastest growing industries in India. Between 1990 and 2010, the Indian fish capture harvest doubled, while aquaculture harvest tripled. In 2008, India was the world's sixth largest producer of marine and freshwater capture fisheries and the second largest aquaculture farmed fish producer. India exported 600,000 metric tonnes of fish products to nearly half of the world's countries.

- The farm suicide rate was 12.9 suicides per 100,000 farmers, which was higher than the general suicide rate at 10.6 in India.

\section{BACKGROUND STUDY}

According to census of India, the following data shows about the percentage of agriculture-workers in total population

\begin{tabular}{|c|c|c|c|}
\hline Year & $\begin{array}{c}\text { Population } \\
\text { (in millions) }\end{array}$ & $\begin{array}{c}\text { Total agri workers } \\
\text { (in millions) }\end{array}$ & $\begin{array}{c}\text { Percentage of agri } \\
\text { workers }\end{array}$ \\
\hline 1951 & 361.1 & 97.2 & 26.92 \\
\hline 1961 & 439.2 & 131.1 & 29.85 \\
\hline 1971 & 548.2 & 125.7 & 22.93 \\
\hline 1981 & 683.3 & 148 & 21.69 \\
\hline 2001 & 1028.7 & 185.3 & 22.76 \\
\hline 2011 & 1210.9 & 234.1 & 21.73 \\
\hline
\end{tabular}

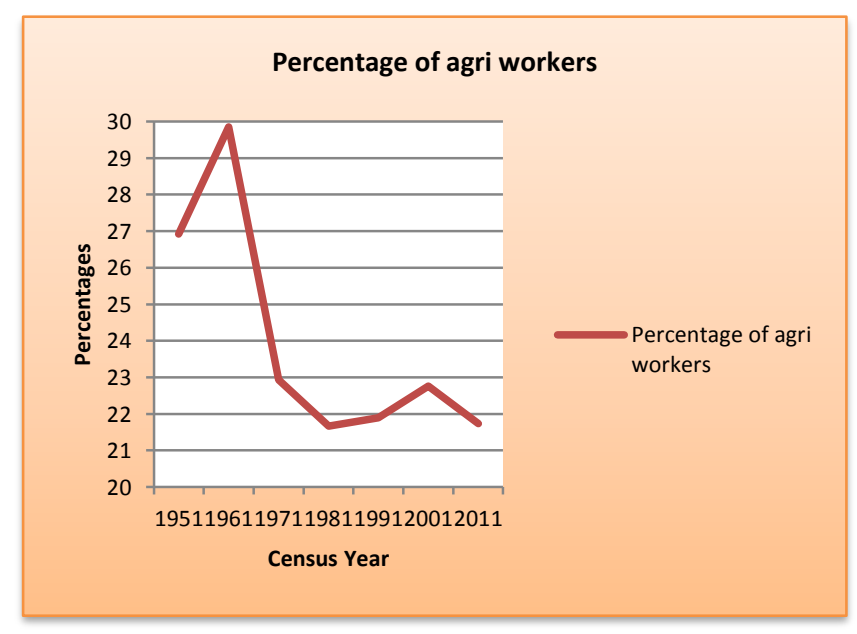

The following data shows the farmer suicides year wise in India 


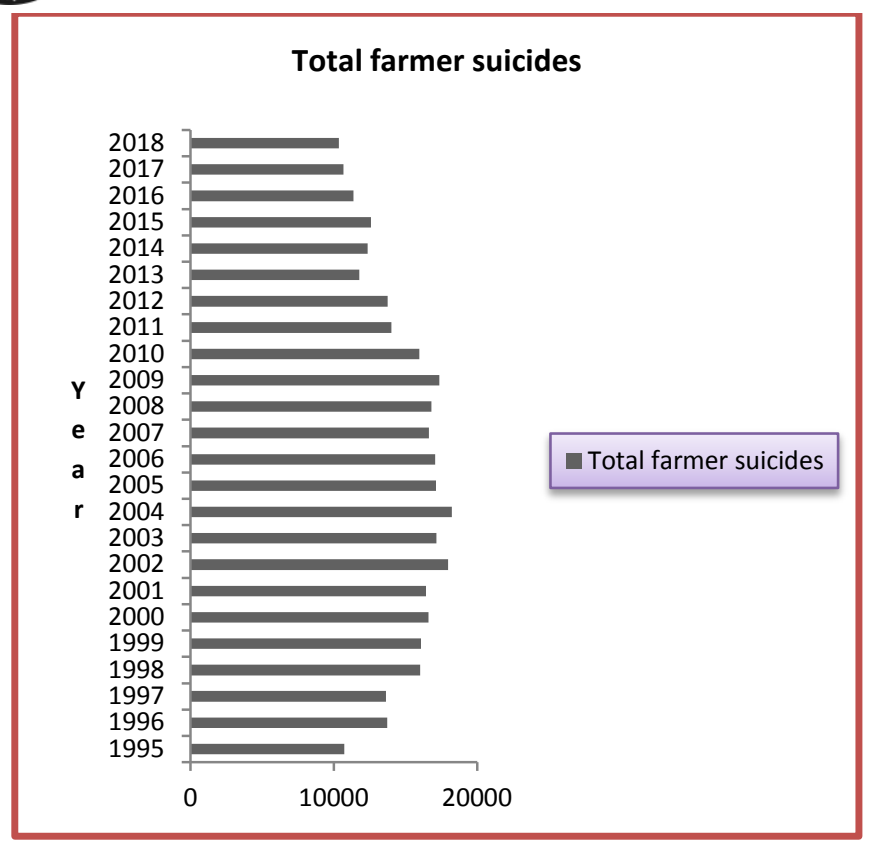

\begin{tabular}{|c|c|c|c|}
\hline Year & Total farmer suicides & Year & Total farmer suicides \\
\hline 1995 & 10720 & 2007 & 16632 \\
\hline 1996 & 13729 & 2008 & 16796 \\
\hline 1997 & 13622 & 2009 & 17368 \\
\hline 1998 & 16015 & 2010 & 15964 \\
\hline 1999 & 16082 & 2011 & 14027 \\
\hline 2000 & 16603 & 2012 & 13754 \\
\hline 2001 & 16415 & 2013 & 11772 \\
\hline 2002 & 17971 & 2014 & 12360 \\
\hline 2003 & 17164 & 2015 & 12602 \\
\hline 2004 & 18241 & 2016 & 11379 \\
\hline 2005 & 17131 & 2017 & 10655 \\
\hline 2006 & 17060 & 2018 & 10349 \\
\hline
\end{tabular}

From the data, we can see that approximately 29 to 30 farmers are killing themselves per day.

\section{RESEARCH GAP}

1) There are many research papers concentrated on how an agri-startup works and how to funding it.

2) This paper focused on agri startups to minimize the farmer suicide rates.

\section{DATA COLLECTION:}

Method of collection: Secondary data

Data Sources: Different organizations authorized websites, Census of India

\section{RESEARCH OBJECTIVE:}

The main objective of this paper is to study about the reasons behind farmer suicides and to minimize the suicide rates, this paper mainly focuses on providing the list of startups required in India which are related to agriculture and how it works.

\section{THEORETICAL ANALYSIS}

Reasons behind farmer suicides:

1) Failure of crops: In India, $17 \%$ of the farmer suicides are due to this reason. There are again several factors for failure of crops

a. Unseasonal rains

b. Genetically modified seeds

c. Quality less seeds

d. Impure fertilizers

e. Droughts or floods

f. Marketing system in India

g. Labor cost

h. Market prices

i. Mediators

j. Lack of proper storage or warehouse facilities.etc.,

2) Loan and debt burden

3) Losses in non-farm activities

4) Borrowing too much for other activities

5) Continuous Stress from bankers and financers.

\section{EXISTING STARTUPS OF AGRICULTURE:}

Agricultural startups in India are still at a embryonic stage, with approximately 300 agripreneurs trying to solve the emerging problems of agri business.

The following is the list of few agri related startups in India which are at early stages only.

\begin{tabular}{|c|c|l|}
\hline S,No & $\begin{array}{c}\text { Name of } \\
\text { startup }\end{array}$ & \multicolumn{1}{|c|}{ Focus Area and Services } \\
\hline 1 & Bohecod & $\begin{array}{l}\text { Bombay Hemp Company assist regional } \\
\text { farmers in cultivating the crop by } \\
\text { providing optimum seeds, best practices }\end{array}$ \\
\hline 2 & Gold Farm & $\begin{array}{l}\text { The aim of this company is to facilitate the } \\
\text { doubling of farm income for a million } \\
\text { farmers in India by 2022 }\end{array}$ \\
\hline 4 & FASAL & $\begin{array}{l}\text { It is an AI powered IOT platform for } \\
\text { agriculture system that records growing } \\
\text { conditions of farm }\end{array}$ \\
\hline 5 & Ninjacart & $\begin{array}{l}\text { Agri marketing platform which connects } \\
\text { fruits and vegetables from farmers to } \\
\text { businesses }\end{array}$ \\
\hline 6 & EM3 Agri & $\begin{array}{l}\text { They provide pay-per use farm services for } \\
\text { the information related to preparation of } \\
\text { land, seed sown, planting, harvesting, post } \\
\text { harvesting etc through mobile application }\end{array}$ \\
\hline Crop In & $\begin{array}{l}\text { Its gathered information on 265 crops and } \\
3500 \text { crop varieties which can be used by } \\
\text { farmers for their farming. }\end{array}$ \\
\hline
\end{tabular}

\section{SUGGESTIONS}

\section{AGRICULTURE STARTUPS REQUIRED IN INDIA:}

\begin{tabular}{|c|c|c|}
\hline $\begin{array}{c}\text { S. } \\
\text { No }\end{array}$ & Focus Area & \multicolumn{1}{c|}{ Focused Services } \\
\hline & Farm to home & $\begin{array}{l}\text { This startup makes farmers to sell } \\
\text { their farming outputs directly to the } \\
\text { consumers without any mediators. } \\
\text { Reason to establish: To benefited } \\
\text { with more profits and no existence }\end{array}$ \\
\hline
\end{tabular}




\begin{tabular}{|c|c|c|}
\hline & & of middle man. \\
\hline 2 & Rental Equipments & $\begin{array}{l}\text { In the current decade technology } \\
\text { plays more role in every field. So } \\
\text { Government or agri entrepreneurs } \\
\text { has to take initiative to supply farm } \\
\text { tech equipments for rental purpose } \\
\text { with affordable prices. } \\
\text { Reason to establish: Lack of } \\
\text { human resources, time saving and } \\
\text { to get more yield. }\end{array}$ \\
\hline 3 & $\begin{array}{l}\text { Agri education (during } \\
\text { day time or evening time) }\end{array}$ & $\begin{array}{l}\text { Not only agricultural universities, } \\
\text { startups has to take a initiative to } \\
\text { teach farmers with new methods of } \\
\text { farming, technologies, trends and } \\
\text { techniques. } \\
\text { Reason to establish: To create } \\
\text { awareness in farmers regarding } \\
\text { new techniques. }\end{array}$ \\
\hline 4 & Preparation of own seeds & $\begin{array}{l}\text { Quality of seeds decreasing day by } \\
\text { day. To eradicate this farmer has to } \\
\text { learn how to prepare the seeds for } \\
\text { their own crop. } \\
\text { Reason to establish: To reduce } \\
\text { cost and to increase the quality of } \\
\text { seeds and crop. }\end{array}$ \\
\hline 5 & $\begin{array}{c}\text { Fertilizers (Vermi- } \\
\text { compost manufacturing) }\end{array}$ & $\begin{array}{l}\text { In olden ages, farmers used to } \\
\text { prepare their fertilizers by } \\
\text { themselves for good quality of } \\
\text { crop. Due to lack of time and } \\
\text { knowledge, farmers buying } \\
\text { unpurified fertilizers which makes } \\
\text { soil erosion, diseases for crop and } \\
\text { unhealthy problems for consumers. } \\
\text { Reason to establish: To use } \\
\text { purified fertilizers (chemical free } \\
\text { fertilizers) for the crop to get more } \\
\text { yield }\end{array}$ \\
\hline 6 & Organic Farming & $\begin{array}{l}\text { T\o teach the farmers about organic } \\
\text { farming techniques. } \\
\text { Reason to establish: Eco-friendly } \\
\text { farming, healthy food and one of } \\
\text { the recent trends in farming }\end{array}$ \\
\hline 7 & Weekend farming & $\begin{array}{l}\text { To take the initiative of working } \\
\text { officials to work on the field on } \\
\text { weekends } \\
\text { Reason to establish: Every person } \\
\text { can close to be nature which makes } \\
\text { more fit. }\end{array}$ \\
\hline 8 & Water management & $\begin{array}{l}\text { A new startup teaching the } \\
\text { technologies to save water while } \\
\text { farming. A technology of Israel } \\
\text { called water gel which will be } \\
\text { given to soil once in a year which } \\
\text { will produce water to a plant entire } \\
\text { year. } \\
\text { Reason to establish: To utilize } \\
\text { less water and to get more yield. }\end{array}$ \\
\hline 9 & Smart farming & $\begin{array}{l}\text { Data collection, Rainfall patterns, } \\
\text { information about crop yields using } \\
\text { smart phones } \\
\text { Reason to establish: To know new } \\
\text { trends in farming and seasonal } \\
\text { plantations. }\end{array}$ \\
\hline 10 & $\begin{array}{l}\text { Mobile Application } \\
\text { (Safeguarding from } \\
\text { thieves and animals) }\end{array}$ & $\begin{array}{l}\text { Sensors should be fixed in and } \\
\text { around of farms, which is } \\
\text { connected to mobile application to } \\
\text { the farmers. } \\
\text { Reason to establish: To reduce }\end{array}$ \\
\hline
\end{tabular}

\begin{tabular}{|c|l|l|}
\hline \multirow{3}{*}{11} & Schemes and Insurances & $\begin{array}{l}\text { losses } \\
\text { Teaching farmers about the } \\
\text { schemes and insurances providing } \\
\text { by government of India } \\
\text { Reason to establish: Without } \\
\text { knowing schemes farmers taking } \\
\text { loans from financers which leads to } \\
\text { deaths. }\end{array}$ \\
\hline \multirow{3}{*}{12} & Agri courses to school & $\begin{array}{l}\text { Reason to establish: A startup to } \\
\text { teach the agriculture related } \\
\text { students }\end{array}$ \\
& & $\begin{array}{l}\text { courses for the school students as } \\
\text { they can know the value of } \\
\text { agriculture and food. }\end{array}$ \\
\hline
\end{tabular}

\section{CONCLUSIONS}

Digital transformation and start-up ecosystem playing a vital role for bringing new innovation in agriculture sector. Since last five years more than five global Agritech compa nies started in India. Still, the suicide rates are not decreasing, if more agri startup's are focusing market linkage, digital agriculture, better access to inputs and financing are gaining attraction, these technological mechanisms help local farming become a sustainable and profit yielding enterprise, then there is a possibility of decreasing farmer suicides as well as to increase the farm production rates.

\section{REFERENCES}

Census of India

NCRB reports for farmer suicides

Websites of agri related startups

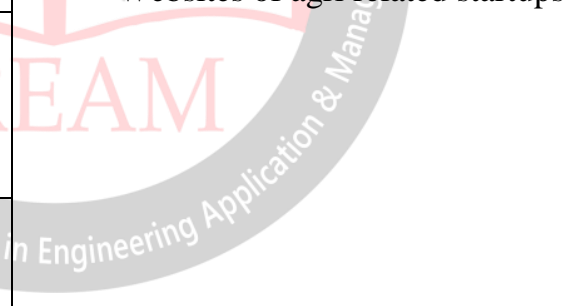

